\title{
Transition of lymphocyte subsets in peritoneal dialysis effluent and its relationship to peritoneal damage
}

\author{
Atsuki Ohashi ${ }^{1}$, Ayaka Yamanishi ${ }^{1}$, Madoka Kondo ${ }^{1}$, Fumitaka Ihara ${ }^{1}$, \\ Tomomi Tanaka ${ }^{1}$, and Yoshitaka Maeda ${ }^{1}$
}

${ }^{1}$ Department of Nephrology, JA Toride Medical Center, Japan

\begin{abstract}
Objective: Peritoneal function during peritoneal dialysis (PD) declines over time due to peritoneal inflammation; however, the immunological mechanism has not been fully clarified. Here, we examined changes in each cellular fraction in the peritoneal dialysis effluent by flow cytometry and their relationship to peritoneal damage.

Patients and Methods: We enrolled 23 patients who began PD between 2006 and 2017 and had available datasets of the peritoneal equilibration test and flow cytometric analysis for at least three consecutive visits, with an interval of six months from six months after introducing PD. The levels and changes in each cellular fraction, dialysate/plasma (D/P) creatinine ratio, and the forward scatter (FSC) ratio of mesothelial cells to lymphocytes were compared using a simple linear regression analysis.

Results: Among the examined variables, only the fraction of $\mathrm{CD} 8^{+} \mathrm{T}_{\mathrm{CM}}$ cells during the first observation was significantly correlated with the change rate in the $\mathrm{D} / \mathrm{P}$ creatinine ratio $\left(\beta=1.47, P=0.001\right.$, adjusted $\left.\mathrm{R}^{2}=0.379\right)$. The $\mathrm{CD} 8^{+}$naïve $\mathrm{T}$ and $\mathrm{CD} 8^{+} \mathrm{T}_{\mathrm{CM}}$ cell fractions were negatively correlated with the change rate of the $\mathrm{D} / \mathrm{P}$ creatinine ratio (naïve $\mathrm{T}$ cells: $\beta=-0.058, P=0.022$, adjusted $\mathrm{R}^{2}=0.188 ; \mathrm{T}_{\mathrm{CM}}$ cells: $\beta=-0.096, P=0.046$, adjusted $\mathrm{R}^{2}=0.137$ ). In addition, the change rates of the $\mathrm{D} / \mathrm{P}$ creatinine ratio tended to be higher, though not significantly (one way ANOVA; $P=0.080$ ), in accordance with the increase in the change rate of the CD8 $8^{+}$effector memory $\mathrm{T}$ cells $\left(\mathrm{T}_{\mathrm{EM}}\right)$.

Conclusion: The $\mathrm{CD} 8^{+}$naïve $\mathrm{T}$ and $\mathrm{T}_{\mathrm{CM}}$ cells may transition into $\mathrm{T}_{\mathrm{EM}}$ cells by repeated exposure to the dialysate over time. The $\mathrm{T}_{\mathrm{EM}}$ cells residing in the peritoneum may play a significant role in the progression of peritoneal damage.
\end{abstract}

Key words: flow cytometry, peritoneal dialysis, encapsulating peritoneal sclerosis

(J Rural Med 2021; 16(4): 200-205)

\section{Introduction}

Morphological and functional changes in the peritoneum may lead to the cessation of peritoneal dialysis (PD) due to fluid overload or develop into encapsulating peritoneal sclerosis (EPS). Encapsulating peritoneal sclerosis is characterized by thickening and fibrosis of the peritoneal membrane, with the formation of a fibrous cocoon that encapsulates the bowel and subsequently induces intestinal obstruction, malnutrition, bowel ischemia, infection, and fatal conditions ${ }^{1)}$.

Received: March 1, 2021

Accepted: May 20, 2021

Correspondence: Atsuki Ohashi, Department of Nephrology, JA

Toride Medical Center, 2-1-1 Hongo, Toride City, Ibaraki 302-0022, Japan

E-mail: atsuki_med1028@yahoo.co.jp

This is an open-access article distributed under the terms of the Creative Commons Attribution Non-Commercial No Derivatives

(c) (†) (by-nc-nd) License $<$ http://creativecommons.org/ CY ${ }_{\mathrm{BY}}$ ND licenses/by-nc-nd/4.0/>
The dialysate IL-6, TNF- $\alpha^{2)}$, PAI-13), CA1254), and serum C-reactive protein ${ }^{5}$, along with the peritoneal equilibration test $(\mathrm{PET})^{6}$, have been suggested as candidate prognostic markers of EPS. However, none of these are satisfactory for the early identification of patients with PD who will develop EPS. Yamamoto et al. reported that the sizes of peritoneal mesothelial cells in the PD effluent correlate significantly with the duration of $\mathrm{PD}$, and large mesothelial cells might reflect peritoneal damage $e^{7}$, although their proposal has limitations in terms of accessibility and simplicity. We focused on flow cytometry for the whole-cell analysis of PD effluent without an invasive risk to patients. We previously reported that forward scatter (FSC) levels of mesothelial cells, which reflect the size of cells, significantly correlated with the dialysate/plasma (D/P) creatinine ratio ${ }^{8}$. In addition, we reported that a lymphocyte fraction of $>60 \%$ and a macrophage fraction of $<10 \%$ may be predictors of EPS ${ }^{9}$. Here, we examined each cellular fraction in the peritoneal effluent by flow cytometry and evaluated their correlation with peritoneal functions. In addition, several reports have indicated 
the involvement of $\mathrm{T}$ cells in peritoneal inflammation, which might lead to peritoneal damage and EPS ${ }^{10,11)}$. Therefore, we focused on lymphocyte subsets in the PD effluent and examined their relationship to the change in peritoneal function, as represented by markers such as the $\mathrm{D} / \mathrm{P}$ creatinine ratio and FSC level of the mesothelial cells.

\section{Patients and Methods}

\section{Patients}

Of the PD patients treated at JA Toride Medical Center between 2006 and 2018, 23 patients (15 male, eight female) with available data of three consecutive PD effluent samplings after the introduction of PD were enrolled in this study after obtaining informed consent. The mean and standard deviation of their age was $64.4 \pm 13.9$ years. The primary diseases of the participants were as follows: seven with diabetic nephropathy, three with benign nephrosclerosis, nine with chronic glomerulonephritis, one with polycystic kidney disease, one with gouty kidney disease, and one with unknown etiology.

The first sample was collected six months after PD introduction to avoid the effects of installment surgeries of the PD catheters on peritoneal tissues. Follow-up sampling was then conducted every six months. Thus, three consecutive samples were taken at 6,12 , and 18 months after PD introduction. Patients with missing data or an episode of peritonitis within 18 months (third sampling) after the PD introduction were excluded. A PET was performed using Twardowski's method at the same time as the flow cytometric analysis.

\section{Flow cytometry}

After 8-hour peritoneal retention of $2.5 \%$ glucose dialysate, $50 \mathrm{~mL}$ of the effluent was collected and centrifuged at $1,800 \mathrm{rpm}$ for $5 \mathrm{~min}$. The collected cellular components were centrifuged again at $1,800 \mathrm{rpm}$ for $5 \mathrm{~min}$, washed with bovine serum albumin-phosphate buffered saline (BSAPBS), and adjusted to $1 \times 10^{7}$ cells $/ \mathrm{mL}$ with BSA-PBS. The detailed processing procedures are described in a previous report $^{8)}$. A FITC-labeled anti-cytokeratin antibody was used to label the mesothelial cells, while PE-labeled anti-CD14 and PreCP-labeled anti-CD45 antibodies were used to label macrophages, lymphocytes, and granulocytes (macrophages were positive for both, lymphocytes were positive for CD45, and granulocytes were weakly positive for CD45). Samples were analyzed using FACSCalibur (BD Biosciences, Tokyo, Japan) and CELLQuest (BD Bioscience). In addition, samples were stained with a three-color $\mathrm{T} / \mathrm{B} / \mathrm{NK}$ panel to determine the percentages of $\mathrm{B}, \mathrm{T}$, and natural killer cells. A more detailed analysis of the $\mathrm{T}$ cell subsets was performed by staining samples with FL-3-labeled CD4 and FL-3-labeled $\mathrm{CD} 8$, and further categorization of $\mathrm{T}$ cells into four subsets was conducted according to the expression patterns of CCR7 and CD45RA.

The expression of CCR7 in combination with the naïve cell marker CD45RA discriminates naïve (CD45RA ${ }^{+}$, $\left.\mathrm{CCR}^{+}\right)$and central memory $\mathrm{T}\left(\mathrm{T}_{\mathrm{CM}} ; \mathrm{CD} 45 \mathrm{RA}^{-}, \mathrm{CCR} 7^{+}\right)$ cells from effector memory $\mathrm{T}\left(\mathrm{CD}^{2} 5 \mathrm{RA}^{-}, \mathrm{CCR}^{-}\right)$cells and TEM-re-expressing CD45RA ( $\mathrm{T}_{\text {EMRA }}$; CD45RA ${ }^{+}, \mathrm{CCR}^{-}$) cells ${ }^{12}$. Because the FSC levels of lymphocytes were less affected by flow cytometric conditions than those of the mesothelial cells, FSC ratios of mesothelial cells to lymphocytes were applied to compare mesothelial cell sizes in different flow cytometric settings.

\section{Statistical analysis}

All statistical analyses were performed using EZR, a graphical user interface for R (The R Foundation for Statistical Computing, Vienna, Austria) ${ }^{13)}$.

Results are shown as the mean \pm standard deviation (SD) unless specified otherwise. The correlation of each variable was evaluated using a simple regression analysis, unless specified. Specifically, the correlation between the change rate of $\mathrm{CD} 8+\mathrm{T}_{\mathrm{EM}}$ and the change rate of the $\mathrm{D} / \mathrm{P}$ creatinine ratio was evaluated by a one-way analysis of variance (ANOVA), where the change rate of $\mathrm{CD} 8+\mathrm{T}_{\mathrm{EM}}$ was divided into three groups in descending order. The correlation between the change rate of $\mathrm{CD} 8^{+} \mathrm{T}_{\mathrm{EM}}$ and that of $\mathrm{CD} 8+\mathrm{T}_{\mathrm{CM}}$ or naïve $\mathrm{T}$ cells was evaluated using the Spearman rank correlation test. The change rate was calculated as the difference between the value of the 1st collection and that of the $3 \mathrm{rd}$ collection, divided by the value of 1 st sample collection.

\section{Results}

Table 1 shows the patient characteristics and flow cytometry results (mean \pm SD of each variable at each visit). Macrophages occupied almost half of the cell population $(51.5 \pm 18.21 \%)$. Lymphocytes, the second largest population, consisted of T cells, while B, NK, and mesothelial cells were the smallest cell populations. Their tendencies did not appear to change significantly over time, but the findings were highly variable, suggesting non-negligible heterogeneity between profiles.

Correlations between the change rate of the $\mathrm{D} / \mathrm{P}$ creatinine ratio over one year and each cellular fraction at the first sample collection were evaluated by a simple regression analysis. As shown in Table 2, only the fraction of CD8 + $\mathrm{T}_{\mathrm{CM}}$ cells was significantly correlated with the change rate of the $\mathrm{D} / \mathrm{P}$ creatinine ratio. No correlation was found between the change rate of the FSC ratio and each cellular fraction in the first samples.

These results suggested that a higher fraction of CD8 + $\mathrm{T}_{\mathrm{CM}}$ cells at six months after the introduction of PD led to a more rapid elevation of $\mathrm{D} / \mathrm{P}$ ratios. Correlations between the 
Table 1 Patient characteristics and each cellular component (means \pm standard deviation) at each sample collection

\begin{tabular}{lcc}
\hline \multicolumn{1}{c}{ Time after PD initiation } & 6 months & 18 months \\
\hline D/P creatinine ratio & $0.65 \pm 0.12$ & $0.68 \pm 0.12$ \\
FSC ratio & $1.69 \pm 0.21$ & $1.67 \pm 0.27$ \\
Lymphocytes $(\%)$ & $19.84 \pm 12.69$ & $23.30 \pm 14.46$ \\
CD4 ${ }^{+}$naïve T cells & $11.67 \pm 8.75$ & $13.61 \pm 12.82$ \\
$\mathrm{CD}^{+}$naïve T cells & $9.53 \pm 8.54$ & $10.82 \pm 8.90$ \\
$\mathrm{CD}^{+} \mathrm{T}_{\mathrm{EM}}$ cells & $46.84 \pm 13.10$ & $48.14 \pm 15.72$ \\
$\mathrm{CD}^{+} \mathrm{T}_{\mathrm{EM}}$ cells & $53.53 \pm 15.80$ & $48.56 \pm 14.42$ \\
$\mathrm{CD} 4^{+} \mathrm{T}_{\mathrm{CM}}$ cells & $37.83 \pm 10.68$ & $34.55 \pm 11.65$ \\
$\mathrm{CD} 8^{+} \mathrm{T}_{\mathrm{CM}}$ cells & $10.28 \pm 6.23$ & $10.04 \pm 6.28$ \\
$\mathrm{CD} 4^{+} \mathrm{T}_{\mathrm{EMRA}}$ cells & $3.66 \pm 2.57$ & $3.69 \pm 2.93$ \\
$\mathrm{CD} 8^{+} \mathrm{T}_{\mathrm{EMRA}}$ cells & $26.66 \pm 10.44$ & $30.59 \pm 11.28$ \\
Macrophages $(\%)$ & $51.23 \pm 18.21$ & $50.49 \pm 17.92$ \\
$\mathrm{~B}$ cells $\left(\mathrm{CD} 19^{+}\right)(\%)$ & $1.82 \pm 2.58$ & $2.88 \pm 5.37$ \\
$\mathrm{NK}$ cells $\left(\mathrm{CD} 56^{+}\right)(\%)$ & $1.47 \pm 1.16$ & $1.82 \pm 1.61$ \\
Mesothelial cells $(\%)$ & $4.16 \pm 5.62$ & $6.06 \pm 9.64$ \\
\hline
\end{tabular}

Table 2 Correlations between the percentage of each cellular fraction at the first sample collection and the change rate of $\mathrm{D} / \mathrm{P}$ creatinine by simple linear regressions

\begin{tabular}{lccl}
\hline & Coefficient $(\beta)$ & Adjusted $\mathrm{R}^{2}$ & $P$-value \\
\hline $\mathrm{CD}^{+}$Naïve T cells & 0.24 & -0.025 & 0.5 \\
$\mathrm{CD}^{+}$Naïve T cells & 0.22 & -0.031 & 0.56 \\
$\mathrm{CD}^{+} \mathrm{T}_{\mathrm{EM}}$ cells & -0.29 & 0.025 & 0.23 \\
$\mathrm{CD}^{+} \mathrm{T}_{\mathrm{EM}}$ cells & -0.062 & -0.043 & 0.76 \\
$\mathrm{CD}^{+} \mathrm{T}_{\mathrm{CM}}$ cells & 0.32 & 0.0096 & 0.28 \\
$\mathrm{CD}^{+} \mathrm{T}_{\mathrm{CM}}$ cells & 1.48 & 0.38 & $0.0010^{*}$ \\
$\mathrm{CD} 4^{+} \mathrm{T}_{\mathrm{EMRA}}$ cells & -0.76 & -0.028 & 0.54 \\
$\mathrm{CD} 8^{+} \mathrm{T}_{\mathrm{EMRA}}$ cells & -0.53 & 0.11 & 0.072 \\
$\mathrm{~B} \mathrm{cell}$ & -1.88 & 0.07 & 0.12 \\
$\mathrm{NK}$ cell & -4.07 & 0.064 & 0.13 \\
\hline
\end{tabular}

$* P<0.05$.

Table 3 Correlations between the change rates of each cellular fraction and $\mathrm{D} / \mathrm{P}$ creatinine by simple linear regressions

\begin{tabular}{lccl}
\hline & Coefficient $(\beta)$ & Adjusted $\mathrm{R}^{2}$ & $P$-value \\
\hline $\mathrm{CD} 4^{+}$Naïve T cells & -0.012 & 0.014 & 0.26 \\
$\mathrm{CD} 8^{+}$Naïve T cells & -0.058 & 0.19 & $0.022^{*}$ \\
$\mathrm{CD} 4^{+} \mathrm{T}_{\mathrm{EM}}$ cells & 0.14 & 0.063 & 0.13 \\
$\mathrm{CD} 8^{+} \mathrm{T}_{\mathrm{EM}}$ cells & 0.17 & 0.085 & 0.096 \\
$\mathrm{CD} 4^{+} \mathrm{T}_{\mathrm{CM}}$ cells & -0.096 & -0.011 & 0.4 \\
$\mathrm{CD} 8^{+} \mathrm{T}_{\mathrm{CM}}$ cells & -0.096 & 0.14 & $0.046^{*}$ \\
$\mathrm{CD} 4^{+} \mathrm{T}_{\mathrm{EMRA}}$ cells & 0.013 & -0.043 & 0.77 \\
$\mathrm{CD} 8^{+} \mathrm{T}_{\mathrm{EMRA}}$ cells & 0.017 & -0.044 & 0.79 \\
$\mathrm{~B}$ cells & -0.017 & 0.036 & 0.19 \\
$\mathrm{NK}$ cells & 0.0045 & -0.046 & 0.88 \\
\hline
\end{tabular}

$* P<0.05$.

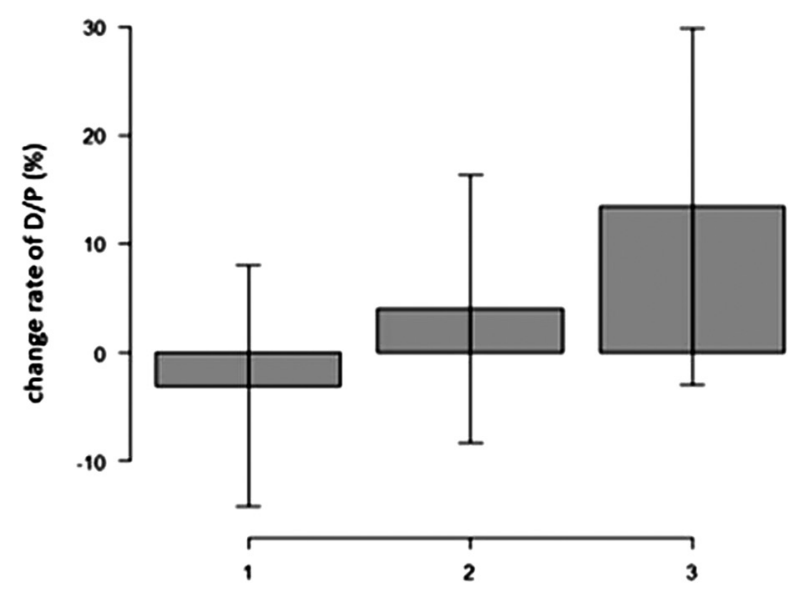

change rate of $\mathrm{CD} 8+$ effector memory $\mathrm{T}$ cells ranked in descending order

Figure 1 Correlation between the change rates of the $\mathrm{CD} 8^{+} \mathrm{T}_{\mathrm{EM}}$ cells and $\mathrm{D} / \mathrm{P}$ creatinine by an ANOVA.

change rate of $\mathrm{D} / \mathrm{P}$ creatinine and that of each cellular fraction were also evaluated. As shown in Table 3, CD8 + naïve $\mathrm{T}$ and $\mathrm{CD} 8+\mathrm{T}_{\mathrm{CM}}$ cells were both significantly correlated with the change rate of the $\mathrm{D} / \mathrm{P}$ creatinine ratio. Moreover, the rate of change of the FSC ratio showed no significant correlation with each cellular fraction. While the $\mathrm{CD}^{+} \mathrm{T}_{\mathrm{EM}}$ cells did not show a significant correlation, the change rate of the $\mathrm{D} / \mathrm{P}$ creatinine ratio tended to be higher in accordance with the increased change rate of $\mathrm{CD} 8+\mathrm{T}_{\mathrm{EM}}$ cells in the stratified analysis $(P=0.080)$ (Figure 1).

In addition, when the correlation between the change rate of $\mathrm{CD}^{+} \mathrm{T}_{\mathrm{EM}}$ cells and that of $\mathrm{CD} 8+\mathrm{T}_{\mathrm{CM}}$ or $\mathrm{CD} 8+$ naivve $\mathrm{T}$ cells were evaluated by the Spearman rank correlation test, both showed negative correlations $\left(\mathrm{T}_{\mathrm{CM}}\right.$ cells: $\rho=-0.40$, $P=0.058$; naïve T cell: $\rho=0.67, P=0.001$ ) (Figure 2).

\section{Discussion}

An increase in the $\mathrm{CD} 8^{+} \mathrm{T}_{\mathrm{EM}}$ cell fraction and a decrease in the $\mathrm{CD} 8+\mathrm{T}_{\mathrm{CM}}$ and naïve $\mathrm{T}$ cell fractions were correlated with an increase in the $\mathrm{D} / \mathrm{P}$ creatinine ratio. In addition, an increase in the $\mathrm{CD} 8+\mathrm{T}_{\mathrm{CM}}$ cell fraction at the first evaluation was correlated with an increase in the $\mathrm{D} / \mathrm{P}$ creatinine ratio. Further analysis revealed that the change in the $\mathrm{CD} 8+$ $\mathrm{T}_{\mathrm{EM}}$ cell fraction was negatively correlated with those of the $\mathrm{CD} 8+\mathrm{T}_{\mathrm{CM}}$ and naïve $\mathrm{T}$ cells, indicating that $\mathrm{CD} 8+\mathrm{T}_{\mathrm{CM}}$ and $\mathrm{CD} 8+$ naïve $\mathrm{T}$ cell fractions might have transitioned into $\mathrm{T}_{\mathrm{EM}}$ cells over time. Based on these results, the $\mathrm{CD} 8^{+} \mathrm{T}_{\mathrm{EM}}$ cells differentiated from $\mathrm{CD} 8+\mathrm{T}_{\mathrm{CM}}$ and naïve $\mathrm{T}$ cells after repeated exposure to cognate antigens derived from PD solution, which may have caused peritoneal inflammation to increase the $\mathrm{D} / \mathrm{P}$ creatinine ratio.

In response to encountering cognate antigens, naïve $T$ cells, which have not been sensitized to any antigen, prolif- 


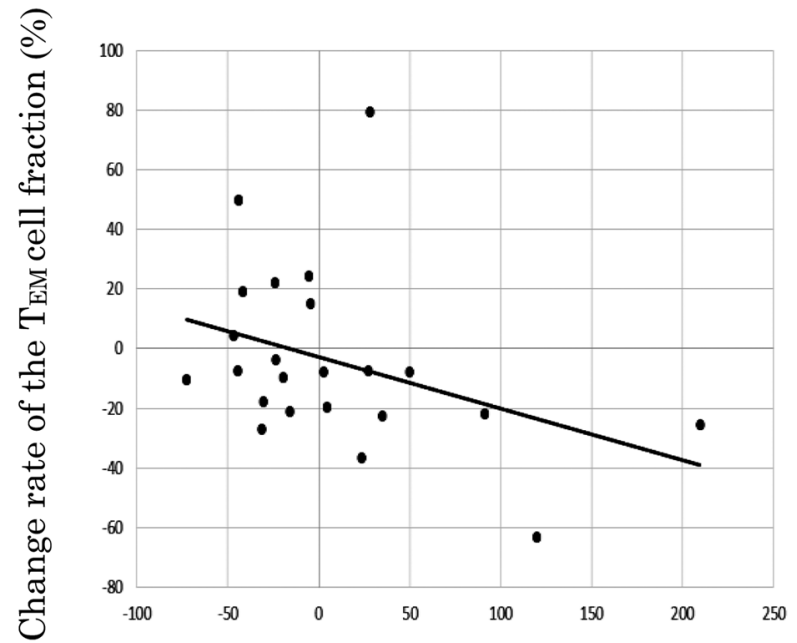

Change rate of the $\mathrm{T}_{\mathrm{CM}}$ cell fraction $(\%)$

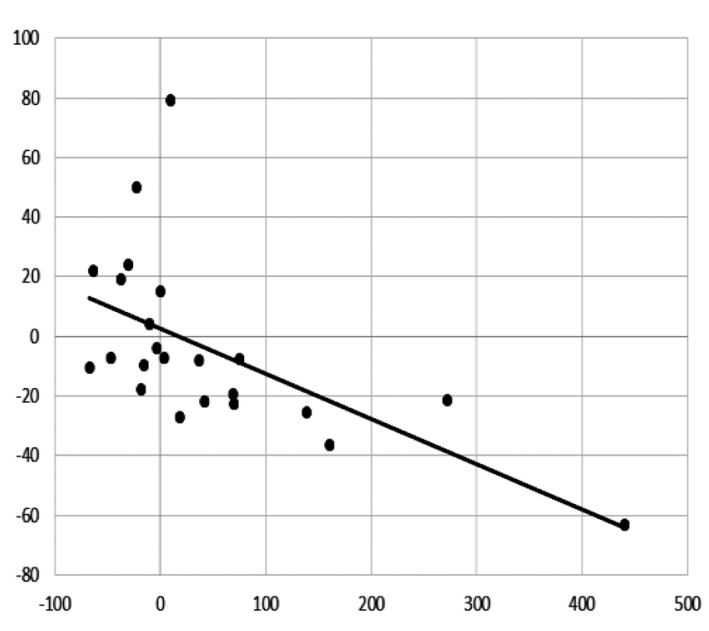

Change rate of the naïve T cell fraction (\%)

Figure 2 Correlation between the change rates of the $\mathrm{T}_{C M}$ and $\mathrm{T}_{\mathrm{EM}}$ cell fractions (left), and the change rates of the Naïve and $\mathrm{T}_{\mathrm{EM}}$ cell fractions (right).

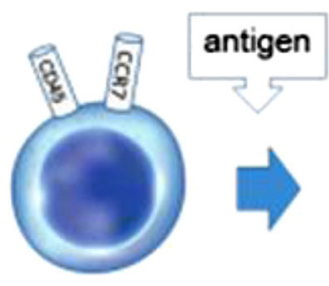

Naive T cell

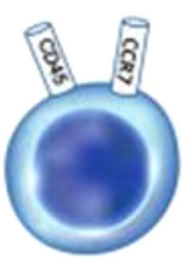

Effector $T$ cell

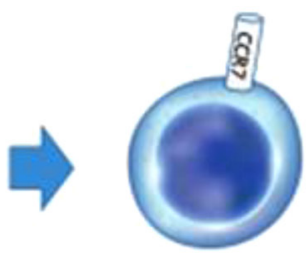

Central memory T cell

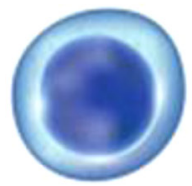

effector memory T cell

Figure 3 Differentiation of memory lymphocytes.

erate and differentiate into effector T cells; the vast majority of these cells migrate to peripheral tissues, while a small pool of effector $\mathrm{T}$ cells ultimately transition into long-lived memory $\mathrm{T}$ cells. Memory $\mathrm{T}$ cells that express CCR7 produce high amounts of IL-2 but low levels of other effector cytokines, while CCR7 ${ }^{-}$memory $\mathrm{T}$ cells produce high levels of IL-4 and IL-5 (CD4 + T cells) and/or IFN- $\gamma$ (both CD4 + and $\mathrm{CD}^{+} \mathrm{T}$ cells). The $\mathrm{CCR} 7^{+}$memory cells are defined as central memory cells because of their potential to reside in secondary lymphoid tissues. Their CCR7- counterparts were named effector memory $\left(T_{E M}\right)$ cells because of their rapid effector functions and potential to reside in peripheral lymphoid tissues ${ }^{14)}$. A subset of $\mathrm{T}_{\mathrm{EM}}$ cells, which express CD45RA (named $\mathrm{T}_{\mathrm{EMRA}}$ cells), display shorter telomeres with limited proliferative and functional capacities, suggesting a terminal differentiation stage (Figure 3$)^{15,16}$.

The results were compatible with a previous report in which most $\mathrm{T}$ cells in the PD effluent were the memory phenotype, with a clear predominance of $\mathrm{CD} 4+/ \mathrm{CD} 8+\mathrm{T}_{\mathrm{EM}}$ cells ${ }^{10)}$. The cytokine profile of CD4 + and CD8 $+\mathrm{T}$ cells was compatible with high levels of proinflammatory TNF- $\alpha$ and IFN- $\gamma$, with less IL-17 and IL-10 ${ }^{10)}$. The CD4 + T cells are consistent with proinflammatory $\mathrm{T}$ helper 1 (Th1) cells. The peritoneal cavity has been reported to be enriched with cells displaying a highly differentiated $\mathrm{T}_{\mathrm{EM}}$ phenotype, and the $\mathrm{T}_{\mathrm{EM}}$ subset starts predominantly early Th1 (IFN $\gamma$ mediated) responses after stimulation with phorbol 12-myristate 13 -acetate/ionomycin ${ }^{17)}$. The mean telomere lengths of peritoneal resident $\mathrm{T}_{\mathrm{EM}}$ cells are significantly shorter than those of the $\mathrm{T}_{\mathrm{EM}}$ cells in the peripheral blood ${ }^{18)}$. This provides compelling evidence for a distinct resident population of $\mathrm{T}_{\mathrm{EM}}$ cells in the peritoneal cavity.

Several animal studies have shown that Th1 responses are crucially involved in the development of peritoneal adhesion and sclerosis ${ }^{18-20)}$. In the development of surgical and post-infectious adhesions in experimental rodent models, the host response is primarily mediated by Th1 cells and is associated with the release of the proinflammatory cytokine IL-17 produced by T cells ${ }^{19)}$. An IL-17-mediated inflammatory response has also been reported to play a major role in peritoneal damage ${ }^{21}$. Despite the implications of Th17 responses in peritoneal fibrosis in animal models, IL-17-pro- 
ducing $T$ cells constitute only a small proportion of cells in the PD effluent of humans ${ }^{10,17}$.

The Th1 responses initiated by $T_{\mathrm{EM}}$ cells play a role in peritoneal inflammation. In our study, the largest lymphocyte cell population was observed in the $\mathrm{T}_{\mathrm{EM}}$ cells in the $\mathrm{PD}$ effluent. However, $\mathrm{CD} 8+\mathrm{T}_{\mathrm{EM}}$ cells showed a significant correlation with $\mathrm{D} / \mathrm{P}$ creatinine ratios, whereas $\mathrm{CD} 4+$ cells did not. Thus, $\mathrm{CD} 8^{+} \mathrm{T}_{\mathrm{EM}}$ cells, rather than $\mathrm{CD} 4^{+} \mathrm{T}_{\mathrm{EM}}$ cells, might be involved in progressive peritoneal damage.

Memory $\mathrm{CD} 8^{+} \mathrm{T}$ cells are a long-lived, antigen-specific population that provides enhanced protective responses to recurrent exposure to the same antigen ${ }^{22,23}$. Memory CD8 + $\mathrm{T}$ cells are divided into two populations: effector and central memory cells. In recent years, a third population (resident memory $\mathrm{T}$ cells) has been identified. Memory cells in the lamina propria do not migrate elsewhere and have a similar memory to $\mathrm{T}_{\mathrm{EM}}$ cells, but are distinct from $\mathrm{T}_{\mathrm{CM}}$ cells $^{24)}$. These cells express much higher levels of CD69 than $T_{E M}$ cells in the spleen and blood ${ }^{25}$. Hence, this cell population is considered as tissue-resident memory $\mathrm{T}$ cells ${ }^{26,27)}$. Migration-associated receptors that distinguish $\mathrm{T}_{\mathrm{RM}}$ cells from $\mathrm{T}_{\mathrm{EM}}$ cells include CXCR3, CXCR6, CCR5, and CCR6. Phenotypic analysis has demonstrated the enhanced expression of the proinflammatory chemokine receptor CCR5 on the $\mathrm{T}_{\mathrm{EM}}$ subset in PD effluent ${ }^{17)}$, indicating that such a $\mathrm{T}_{\mathrm{EM}}$ cell population might be $\mathrm{T}_{\mathrm{RM}}$ cells. Unfortunately, CD45RA and CCR7 could not distinguish these subsets. In a study of psoriasis ${ }^{28}$, resident $\mathrm{T}_{\mathrm{EM}}$ (possibly $\mathrm{T}_{\mathrm{RM}}$ ) cells produced IL-12, IL-22, IFN $\gamma$, and granzyme A/B.

The $\mathrm{T}_{C M}$ cells retain longer telomeres than $\mathrm{T}_{\mathrm{EM}}$ cells and are capable of generating $\mathrm{T}_{\mathrm{EM}}$ cells in vitro, but not vice versa $^{14)}$. Decreases in $T_{C M}$ and naïve $T$ cell subsets occurred in accordance with an increase in the $T_{E M}$ cell subset over time, suggesting a transition from $T_{C M}$ and naïve $T$ cells to $T_{E M}$ cells. The fraction of $T_{C M}$ cells at the first evaluation was correlated with an increase in $\mathrm{D} / \mathrm{P}$ creatinine. It is reasonable that sensitized $\mathrm{T}_{\mathrm{CM}}$ cells transitioned gradually into $\mathrm{T}_{\mathrm{EM}}$ cells by repeated exposure to cognate antigens, eventually causing chronic inflammation in the peritoneum. However, the role of $\mathrm{CD} 8^{+} \mathrm{T}_{\mathrm{EM}}$ cells in the development of peritoneal fibrosis has not been clarified, and further analysis is needed.

Regarding the absence of any correlation between cellular components and FSC ratios, a one-year observation period might be too short to evaluate subtle differences in the variables to calculate FSC ratios. A longer period is required to assess the significance of these ratios in peritoneal damage.

There are obvious limitations in this study, such as the retrospective nature of the data collection, the limited number of enrolled patients, and the relatively short observation period. The treatment plans were determined by each attending physician, which might have caused biases. In addition, the dialysis adequacy of each patient was not considered in this study, which might be a potential confounding factor that has been reported to affect peritoneal damage. Finally, this study only focused on the cells in the effluent, which might not be consistent with the cells in the peritoneum. Data on cytokines produced by lymphocytes are also lacking. A more precise analysis of the molecules of the peritoneum will be needed to further clarify the mechanisms of peritoneal inflammation.

\section{Conclusion}

The cellular fraction of the PD effluent mainly consisted of macrophages and $\mathrm{T}$ lymphocytes. The largest subset of $\mathrm{T}$ lymphocytes was $\mathrm{T}_{\mathrm{EM}}$ cells. Changes in $\mathrm{T}$ lymphocyte subsets were correlated with changes in $\mathrm{D} / \mathrm{P}$ ratios. The $\mathrm{CD} 8+$ naïve $\mathrm{T}$ and $\mathrm{T}_{\mathrm{CM}}$ cells may transition into $\mathrm{T}_{\mathrm{EM}}$ cells by repeated exposure to the non-physiological solution in the dialysate over time. The $\mathrm{CD} 8^{+} \mathrm{T}_{\mathrm{EM}}$ cells residing in the peritoneum may have a significant role in peritoneal inflammation by producing high levels of cytotoxic cytokines in coordination with $\mathrm{T}$ helper cells.

\section{Acknowledgments}

We thank Chiaki Takei and the related medical staff at the dialysis center of JA Toride Medical Center for data collection.

\section{References}

1. Othman M, Al Malki H, Al Ali F, et al. Encapsulating peritoneal sclerosis: a rare devastating peritoneal disease: case series and literature review. Open J Nephrol 2019; 09: 115-126. [CrossRef]

2. Lambie MR, Chess J, Summers AM, et al. GLOBAL Fluid Study Investigators Peritoneal inflammation precedes encapsulating peritoneal sclerosis: results from the GLOBAL Fluid Study. Nephrol Dial Transplant 2016; 31: 480-486. [Medline] [CrossRef]

3. Lopes Barreto D, Krediet RT. Current status and practical use of effluent biomarkers in peritoneal dialysis patients. Am J Kidney Dis 2013; 62: 823-833. [Medline] [CrossRef]

4. Ho-dac-Pannekeet MM, Hiralall JK, Struijk DG, et al. Longitudinal follow-up of CA125 in peritoneal effluent. Kidney Int 1997; 51: 888-893. [Medline] [CrossRef]

5. Habib SM, Korte MR, Betjes MGH. Lower mortality and inflammation from post-transplantation encapsulating peritoneal sclerosis compared to the classical form. Am J Nephrol 2013; 37: 223-230. [Medline] [CrossRef] 
6. Nakayama M. The greater incidence of encapsulating peritoneal sclerosis is not the result of overdiagnosis. Perit Dial Int 2001; 21(Suppl 3): S72-S74. [Medline] [CrossRef]

7. Yamamoto T, Izumotani T, Otoshi T, et al. Morphological studies of mesothelial cells in CAPD effluent and their clinical significance. Am J Kidney Dis 1998; 32: 946-952. [Medline] [CrossRef]

8. Kanda E, Takai K, Maeda Y, et al. [Flow cytometric analysis of mesothelial cells in peritoneal dialysis effluent]. Nippon Jinzo Gakkai Shi 2005; 47: 100-106 (in Japanese). [Medline]

9. Yoshida S, Tanaka T, Kawasaki T, et al. Flow cytometric analysis of peritoneal dialysis effluent for predicting encapsulating peritoneal sclerosis. Kidney and Dialysis. 2014; 77 : 255-256.

10. Betjes MGH, Habib MS, Struijk DG, et al. Encapsulating peritoneal sclerosis is associated with T-cell activation. Nephrol Dial Transplant 2015; 30 : 1568-1576. [Medline] [CrossRef]

11. Liappas G, González-Mateo GT, Sánchez-Díaz R, et al. Immune-regulatory molecule CD69 controls peritoneal fibrosis. J Am Soc Nephrol 2016; 27: 3561-3576. [Medline] [CrossRef]

12. Sallusto F, Kremmer E, Palermo B, et al. Switch in chemokine receptor expression upon TCR stimulation reveals novel homing potential for recently activated T cells. Eur J Immunol 1999; 29: 2037-2045. [Medline] [CrossRef]

13. Kanda Y. Investigation of the freely available easy-to-use software 'EZR' for medical statistics. Bone Marrow Transplant 2013; 48: 452-458. [Medline] [CrossRef]

14. Sallusto F, Lenig D, Förster R, et al. Two subsets of memory T lymphocytes with distinct homing potentials and effector functions. Nature 1999; 401: 708-712. [Medline] [CrossRef]

15. Romero P, Zippelius A, Kurth I, et al. Four functionally distinct populations of human effector-memory CD8+ T lymphocytes. J Immunol 2007; 178: 4112-4119. [Medline] [CrossRef]

16. Geginat J, Lanzavecchia A, Sallusto F. Proliferation and differentiation potential of human CD8+ memory T-cell subsets in response to antigen or homeostatic cytokines. Blood 2003; 101: 4260-4266. [Medline] [CrossRef]

17. Roberts GW, Baird D, Gallagher K, et al. Functional effector memory T cells enrich the peritoneal cavity of patients treated with peritoneal dialysis. J Am Soc Nephrol 2009; 20: 1895-1900. [Medline] [CrossRef]

18. Chung DR, Chitnis T, Panzo RJ, et al. CD4+ T cells regulate surgical and postinfectious adhesion formation. J Exp Med 2002; 195: 1471-1478. [Medline] [CrossRef]

19. Fielding CA, Jones GW, McLoughlin RM, et al. Interleukin-6 signaling drives fibrosis in unresolved inflammation. Immunity 2014; 40: 40-50. [Medline] [CrossRef]

20. Tzianabos AO, Holsti MA, Zheng XX, et al. Functional Th1 cells are required for surgical adhesion formation in a murine model. J Immunol 2008; 180: 6970-6976. [Medline] [CrossRef]

21. Rodrigues-Díez R, Aroeira LS, Orejudo M, et al. IL-17A is a novel player in dialysis-induced peritoneal damage. Kidney Int 2014; 86: 303-315. [Medline] [CrossRef]

22. Doherty PC, Hou S, Tripp RA. CD8+ T-cell memory to viruses. Curr Opin Immunol 1994; 6: 545-552. [Medline] [CrossRef]

23. Mackay CR, Marston WL, Dudler L. Naive and memory T cells show distinct pathways of lymphocyte recirculation. J Exp Med 1990; 171 : 801-817. [Medline] [CrossRef]

24. Masopust D, Jiang J, Shen $\mathrm{H}$, et al. Direct analysis of the dynamics of the intestinal mucosa CD8 T cell response to systemic virus infection. J Immunol 2001; 166: 2348-2356. [Medline] [CrossRef]

25. Masopust D, Vezys V, Usherwood EJ, et al. Activated primary and memory CD8 T cells migrate to nonlymphoid tissues regardless of site of activation or tissue of origin. J Immunol 2004; 172: 4875-4882. [Medline] [CrossRef]

26. Wakim LM, Waithman J, van Rooijen N, et al. Dendritic cell-induced memory T cell activation in nonlymphoid tissues. Science 2008; 319: 198-202. [Medline] [CrossRef]

27. Gebhardt T, Wakim LM, Eidsmo L, et al. Memory T cells in nonlymphoid tissue that provide enhanced local immunity during infection with herpes simplex virus. Nat Immunol 2009; 10: 524-530. [Medline] [CrossRef]

28. Cheuk S, Wikén M, Blomqvist L, et al. Epidermal Th22 and Tc17 cells form a localized disease memory in clinically healed psoriasis. J Immunol 2014; 192: 3111-3120. [Medline] [CrossRef] 